\title{
Technology acceptance and purchase intention towards 3G technology among millennial smart phone users: A case of Pakistan
}

\author{
Muhammad Jasim Haroon ${ }^{a}$, Imran Qadir ${ }^{b *}$ and Yaser Zaman ${ }^{a}$
}

${ }^{a}$ Masters Student, University of Hairpur, Department of Management Sciences, University of Haripur, Hattar Road, Haripur, Pakistan ${ }^{b}$ Lecturer at Department of Management Sciences, University of Haripur, Haripur, Pakistan

\begin{tabular}{l}
\hline C H R O N I C L E \\
\hline Article history: \\
Received June 5, 2016 \\
Received in revised format \\
October 2, 2016 \\
Accepted November 2, 2016 \\
Available online \\
November 9, 2016 \\
\hline Keywords: \\
Technology acceptance model \\
3G technology \\
Millennials \\
Haripur \\
Pakistan
\end{tabular}
\section{A B S T R A C T}

\begin{abstract}
This study aims to investigate the technology acceptance and purchase intention for Third Generation (3G) technology in Pakistan's telecom sector. In such respect, Technology Acceptance Model (TAM) has been used to find the effects of the independent variables (Perceived Usefulness, Perceived Ease of Use, Perceived Value, Perceived Enjoyment, Personal Innovativeness and Price) on dependent variable (purchase intention). The study population consisted of smartphone users among Millennials in district Haripur-a region in transition towards urbanization. 200 respondents provided the useable data. The results of the study show that perceived usefulness, perceived ease of use, perceived value, perceived enjoyment, personal innovativeness, and price have a significant and positive relationship with purchase intention which validates the growing acceptance of advanced technologies in such regions.
\end{abstract}

\section{Introduction}

Last two decades have seen a tremendous development and growth in the usage of information technology (Chen et al., 2011). Every technology is evolving partially or completely and even small children have access to readily moved phones with peripatetic technologies like broadband (Ali \& M, 2013). Mobile phones help in development and maintaining of relationships among businesses and people. Different people use cell phones to communicate and connect them with their social circles and many use it as a symbol of personality and uniqueness (Grant \& O' Donohoe, 2007). Due to rapid changes in technology, cell phones are evolving at a fast pace. According to Ting et al. (2011) and Persaud and Azhar (2012), the users of cell phones are experiencing changes from way of communication with the multimedia device known as smartphones. The entry of the smart phones introduces a rapid growth and has removed many other industries from the market. Multiple tasks can be performed through a smart phone. This feature of smart phones makes it popular all over the world and Pakistan is not behind. According to a survey, about 5 percent of cell phone users in Pakistan have a smart phone (Adclout, 2013). So with the changes and growth in the smart phones also come the

* Corresponding author.

E-mail address: imran@uoh.edu.pk (I. Qadir)

(C) 2017 Growing Science Ltd. All rights reserved. doi: $10.5267 /$ j.msl.2016.11.003 
changes in mobile services (Ali et al., 2015). As in Pakistan, 3G was introduced in July, 2014 after 1G and 2G. Third-generation (3G) mobile communication technology has augmented bandwidth, protected swiftness and proficiency of data broadcast, as well as improved the speed and capability of data recovery. Thus, the discovery of the $3 \mathrm{G}$ wireless communication system certainly offers an advanced wireless bandwidth and more varied video and audio facilities to clients than formerly (Kuo \& Yen, 2009). Pakistan is among those countries that are using the information technology and adopting the new technologies of the time. Different companies introduced $3 \mathrm{G}$ technology in Pakistan and the ratios of the users are significant. To make them satisfied and estimating their level of satisfaction, it is mandatory to check that whether they are willing to use this technology in future and up to what grounds they are using it? This research study was conducted in district Haripur, Pakistan for the very first time to check out the technology acceptance and the purchase intention of $3 \mathrm{G}$ technology among the users of Millennials age group. TAM is important indicator for $3 \mathrm{G}$ both of whom are broadly used all over the world (Pagani, 2004). Until know, there is no significant research in Pakistan showing the acceptance of $3 \mathrm{G}$ technology in transitional districts like Haripur. This study aims to investigate the technology acceptance and purchase intention of 3G technology among millennial smart phone users in district Haripur, Pakistan.

\section{Literature review}

\subsection{Technology acceptance model (TAM)}

TAM, originally developed by Davis (1989), is a research model for studying the factors of information structure and information technology acceptance to forecast aim to utilize and approval of information system and information technology through people. In two ways TAM is exclusive from Theory of Reasoned Action (TRA). First TAM initiated two new concepts-perceived ease of use which is 'anticipation that a technology involves slightest effort' and perceived usefulness which is 'an acuity that the practice of a technology can boost performance of assignment at hand' (Davis \& Venkatesh, 1996). Perceived ease of use and perceived usefulness both in TAM could forecast one's behavior regarding the utilization of an application. Secondly, TAM has evolved for new technologies to incorporate objectivity (Legris et al., 2003; Serenko et al., 2008) by introduction of new predictors other than the two mentioned by Davis et al. (1989).

\subsection{TAM and various technologies}

Initially TAM was used to estimate the market trend for leading investments in newly developed technologies. For such purpose, a range of then developing personal computers were used in arena of multi-media, pen-based computing and image processing. (Davis \& Venkatesh, 1996). According to Gefen (2000), TAM has been applied both inside and outside the organization to a number of different samples and user groups like groupware (Taylor \& Todd, 1995). Forecasters like self-efficacy, experience, gender and culture were also used to extend TAM in various studies. Ngai et al. (2007) used TAM to see the impact of technical support as a forerunner and afterward explored the part of the extended model in consumer acceptance of Web CT web course tools. The outcomes show the significance of perceived ease of use and perceived usefulness in dominating the relationship of technological growth with attitude and Web CT usage. Elliott and Fu (2008) used TAM to see the impact of adoption model in view of the TAM and TRA to inspect the effect of three particular deals strategies which are product-focused, competitive-focused, and customer-focused on the acceptance of a consumer technology development.

Lin et al. (2010) used TAM to understand the impact of purchaser inspiration and the fulfillment of online consumers while making a purchase. Sung and Yun (2010) used TAM to understand the impact of Perceived Enjoyment (PE) and what determinants can add to PE in the context of mobile media service utilization. It was found that PE impacts Perceived Usefulness (PU) and Perceived Ease of Use 
(PEOU) and specifically Behavior Intention (BI). Yulihasri and Islam (2011) used TAM to see the impact of student's purchasing intention through web shopping in an establishment of higher learning in Malaysia. Usefulness, ease of use and security has been discovered to be vital forecaster toward attitude in on-line shopping. Shroff et al. (2011) used TAM to understand the impact of students' behavioral intention to utilize an electronic portfolio framework. The study summarized that students' perceived ease of use (PEOU) had an important impact on attitude towards utilization (ATU). Afterward, perceived ease of use (PEOU) had the strongest critical impact on perceived usefulness (PU). Zarrad and Debabi (2012) used TAM for online purchasing behavior and reported that past experience about (PEOU) and (PU) were the most critical components in determining online shopping intention.

Bamoriya and Singh (2012) used TAM to see the impact of mobile consumers' intentions to get SMS publicizing in India. The study recommended that to raise acceptance of SMS promotion, advertisers ought to concentrate more on growing utility of SMS advertisements, so that users would create optimistic attitudes towards SMS publicizing. Liang et al. (2013) used TAM to understand customer mindfulness and readiness to utilize hypermarket e-shopping destinations. The outcomes demonstrate that customers' trust on e-shopping sites applies essentially positive outcome on perceived usefulness and perceived ease of use. Also, customers' flow experience essentially impacts perceived usefulness of the e-shopping sites and e-shopping utilization intention. Richard and Hong (2014) used TAM for measuring the impact of online promotions on purchase intention of customers. They found that by increasing customers' perception of ease of use and by decreasing customer's perceived risk, online sales promotion has a noteworthy impact on their purchasing intention. Abu Bakar and Bidin (2014) used TAM in their study and reported that TAM model has greater use in movie mobile advertising. Maoyan et al. (2014) used TAM to understand the impact of social media marketing (SMM) environment on talks about the features of customer buy intention. The outcomes demonstrate that social media marketing stimulate outside factors and afterward impact the buyer's internal perception elements. Finally, it will influence buyers' purchase intention.

\section{$2.33 G$ and technology acceptance model}

Pagani (2004) used TAM to find out the relationship between 3G and TAM and show that there exist significant positive relationships between $3 \mathrm{G}$ and TAM. Phuangthong and Malisawan (2005) used TAM to measure the effects of different factors that affect the adoption of $3 \mathrm{G}$. They discovered that TAM is helpful in understanding and adopting 3G internet on Smartphone. Karjaluoto (2006) used TAM and showed that standardization, user acceptance, and pricing, were the most influential factors. Kuo and Yen (2008) used TAM to understand the customer's behavioral intention to utilize 3G mobile value-added services. Consequences of this study give an important reference to service developers to create mobile value-added services. Singh et al. (2010) used TAM to study 3rd generation (3G) services in India. They found perceived usefulness having the most significant relationship while perceived risk and cost adoption were found to be significant. The number of third generation (3G) users has enlarged considerably which demonstrates its importance as a wireless technology which can provide more broad contents than other wireless services (Suk, 2011). Suki and Suki (2011) used TAM and found that perceived usefulness, perceived ease of use and attitude are the determining factors of users' intention to utilization of $3 \mathrm{G}$ mobile services, its influencing users' intention towards utilizing $3 \mathrm{G}$ mobile service and found that perceived usefulness, perceived ease of use and attitude to be that most critical variables.

Mardikyan et al. (2012) analyzed the components influencing 3G technology perception and acceptance. They found that perceived usefulness, variety of $3 \mathrm{G}$ services, service quality and social influence were the main antecedents of behavioral intention of 3Gacceptance. Garg and Garg (2013) used an extended TAM model to investigate the $3 \mathrm{G}$ utilization. They concluded that social influence impacts the ease of use and perceptions of price were found to impact perceptions of the usefulness, 
which in turn, influences on the pricing policy for operators. Kumar and Sikri (2013) argued that TAM is an extremely robust model in forecasting the utilization of the mobiles and PC technology. They found that behavior intention, perceived quality, perceive enjoyment, ease of use, and perceive usefulness, price level utilizing social influence and encouraging conditions are the most important factors. Lin et al. (2015) also used TAM to study the factors effecting $3 \mathrm{G}$ mobile service acceptance in Taiwan. Results show that perceived need and perceived enjoyment were key components in acceptance of $3 \mathrm{G}$ services.

\section{$2.43 G$ and TAM in Pakistan}

Fida and Ahmed (2014) studied the relationship of consumer attitude with service innovation. They considered $3 \mathrm{G}$ as a service innovation in the Pakistani context. They found that perceived ease of use, perceived price fairness, fashion consciousness had a positive significant relationship to the customer attitude towards service innovation. As apparent from the discussed literature, TAM has been used in multiple researches for emerging new technologies especially in the field of information technology. There have been some studies internationally which have evaluated the $3 \mathrm{G}$ technology using TAM as mentioned earlier in literature.

In Pakistan, TAM has been used for technologies other than 3G many times but 3G technology's acceptance and purchase intention among Pakistani consumers have not been thoroughly and dedicatedly studied. Moreover, the importance of this research is more vital in regions which are in transition towards urbanization. In this study, we have endeavored to check the technology acceptance and purchase intention of 3G technology among smartphone users from Millenniums age group in district Haripur, Pakistan. The model has been adopted from previous studies (Bakara \& Bidin, 2013; Baran, 2009; Agarwal et al., 2007; Childers, 2001; Moon \& Kim, 2001).

\section{Research methodology}

\subsection{Theoretical Framework}

There is one dependent variable namely purchase intention and six independent variables of technology acceptance namely perceived usefulness, perceived ease of use, perceived value, perceived enjoyment, personal innovativeness, price and purchase intention

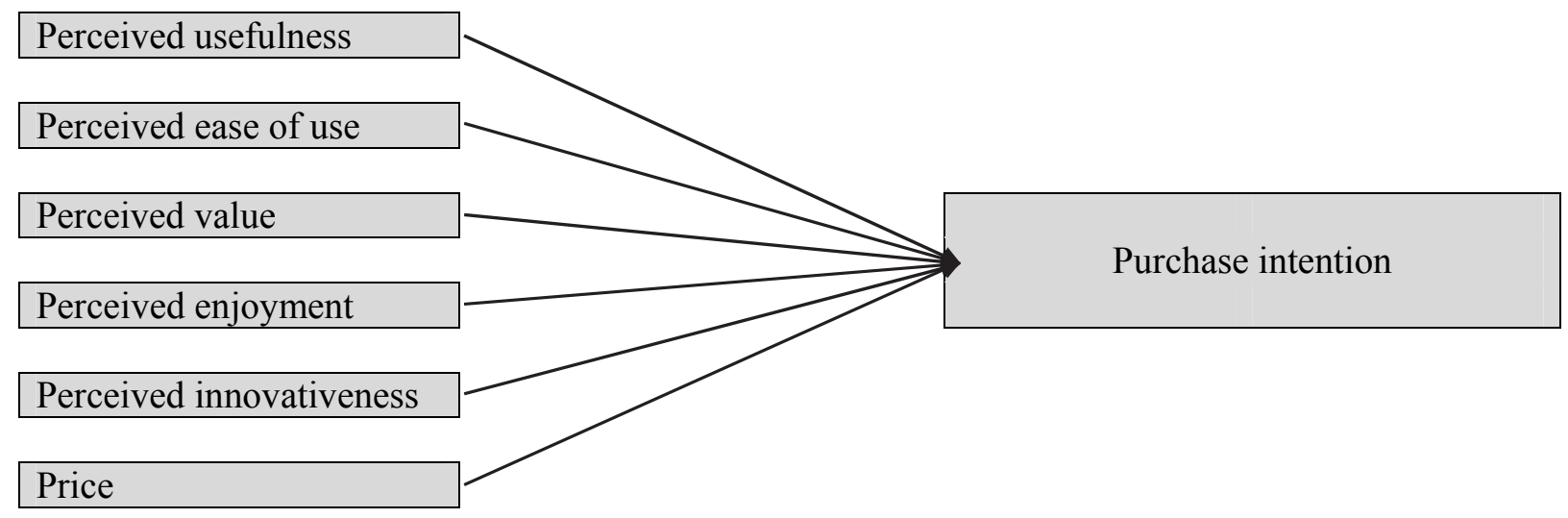

Fig. 1. Theoretical framework

(Adopted from Bakara \& Bidin, 2013; Baran, 2009; Agarwal et al., 2007; Childers, 2001; Moon \& Kim, 2001) 


\subsection{Population}

The population of this study comprises of all the smart phone users in Pakistan belonging to the Millennium age group (15 to 33 years) of regions which are in the transitional stage from rural culture to urbanization.

\subsection{Sample and sampling technique}

Haripur district was selected for data collection on the basis of purposive plus convenient sampling because of two reasons. Firstly, it is in a transitional stage from a rural culture to urbanization and one of the main characteristics of such regions is their acceptance and inclination towards advance technologies (Kates et al., 2006). So, studies like these can predict to some extent their levels of acceptance for new technologies. Secondly, time and financial limitations also were responsible for selection of district Haripur. This was followed by selection of university and college on the basis of cluster sampling. Then convenient and simple random samplings were used to gather data from the university and college students as they form the bulk of smart phone users belonging to the Millennials age group. Some questionnaires were filled through structured interviews while most were provided with questionnaire to be filled on their convenience and then returned on the agreed time and date.

\subsection{Hypotheses}

$H_{1}$ : Perceived Usefulness positively affects purchase intention of $3 G$ mobile service among Millennium smart phone users.

$\mathrm{H}_{2}$ : Perceive Ease of Use positively affects purchase intention of $3 G$ mobile service among Millennium smart phone users.

$H_{3}:$ Perceived value positively affects purchase intention of $3 G$ mobile service among Millennium smart phone users.

H4: Perceived enjoyment positively affects purchase intention of $3 G$ mobile service among Millennium smart phone users.

H5: Personal innovativeness positively affects purchase intention of $3 G$ mobile service among Millennium smart phone users.

H6: Price negatively affects purchase intention of $3 G$ mobile service among Millennium smart phone users.

\section{Results}

Three statistical techniques were used for data analysis namely descriptive statistics, regression analysis and correlation analysis.

\subsection{Descriptive statistics for demographic variables}

The descriptive statistics includes gender, age, education level, occupation, income level, and mobile network usage and $3 \mathrm{G}$ technology. Among the respondents, $63.5 \%$ were male and $36.5 \%$ were female. All of the respondents belonged to the millennial age group from which 15 to 25 years were $90 \%$ and 26 to 33 years were $10 \%$. Under graduates were $57.5 \%$, graduates were $42.0 \%$ and college students were $5 \%$. Students were $98 \%$ and entrepreneurs were $2 \%$. The respondents having house hold monthly income under Rs. 20,000 were $51 \%, 20,000$ to 29,900 were $17.3 \%, 30,000$ to 60,000 were $13.9 \%$, and above 60,000 are $16.8 \%$. Mobilink users were $14.4 \%$, Ufone users were $25.7 \%$, Telenor users were $21.3 \%$, Zong users were $28.7 \%$ and Warid users were $8.9 \% .100 \%$ respondents were using $3 \mathrm{G}$ technology. As per the skewness values provided in Table 1, it is evident that the data is normally distributed. 


\section{Table 1}

Showing Descriptive Statistics showing Skewness

\begin{tabular}{|c|c|c|c|c|}
\hline & \multirow{2}{*}{$\begin{array}{c}\mathrm{N} \\
\text { Statistic }\end{array}$} & \multirow{2}{*}{$\begin{array}{c}\text { Mean } \\
\text { Statistic }\end{array}$} & \multicolumn{2}{|c|}{ Skewness } \\
\hline & & & Statistic & Std. Error \\
\hline $\mathrm{PU}$ & 200 & 3.6920 & -.746 & .172 \\
\hline PEU & 200 & 3.4840 & -.269 & .172 \\
\hline PV & 200 & 3.5400 & -.281 & .172 \\
\hline PE & 200 & 3.5890 & -.308 & .172 \\
\hline PIN & 200 & 3.4550 & -.174 & .172 \\
\hline $\mathrm{P}$ & 200 & 3.4717 & .196 & .172 \\
\hline PI & 200 & 3.8090 & -.501 & .172 \\
\hline Valid N (listwise) & 200 & & & \\
\hline
\end{tabular}

\subsection{Correlation}

In this research study correlation is used in order to found out how much strength is there among the relationship of independent and dependent variables and the results are shown in Table 2.

Table 2

Showing Pearson correlation among variables

\begin{tabular}{cccccccccccccc}
\hline & \multicolumn{2}{c}{ PEOU } & \multicolumn{2}{c}{ PU } & \multicolumn{2}{c}{ PV } & \multicolumn{2}{c}{ PI } & \multicolumn{2}{c}{ P } & \multicolumn{2}{c}{ PE } \\
\hline \multirow{2}{*}{ PI } & R & Sig. & R & Sig. & R & Sig. & R & Sig. & R & Sig. & R & Sig. \\
\hline & .000 & $.437^{* *}$ & .000 & $.390^{* *}$ & .000 & .433 & .000 & $.301^{* *}$ & .000 & $.461^{* *}$ & .000 \\
\hline **. Correlation is significant at the 0.01 level (2-tailed) & & & & & & & &
\end{tabular}

\subsection{Regression analysis}

Regression analysis has multiple use, mostly its value shows

- Strength of the connection

- Direction of the relationship (positive, negative, zero)

- Goodness of model fit.

In Table " $\mathrm{R}$ " stands for Multiple Correlation Coefficient and its outcome value is 0.599 , And R Square tell us the ratio of interdependence and its outcome value is 0.359 , Adjusted $\mathrm{R}$ Square value is 0.339 which is when multiplied by 100 to convert it into percentage then comes to $35 \%$ which means that $35 \%$ of the Variance in purchase intention can be predicted by Independent variables like perceived usefulness, perceived ease of use, perceived value, perceived enjoyment, personal innovativeness and price.

Table 3

Model summary

\begin{tabular}{lcccc}
\hline Model & $\mathrm{R}$ & R Square & Adjusted R Square & Std. Error of the Estimate \\
\hline 1 & $.599^{\mathrm{a}}$ & .359 & .339 & .60756
\end{tabular}

Table 3, shows the regression results for the relationship of dependent and independent variables. The first hypothesis shows the effect of perceived usefulness on purchase intention and found a significant relationship with a positive value of.437 and $\mathrm{B}$ value is 0.289 . The second hypothesis shows the 
effect of perceived ease of use on purchase intention and found a significant relationship with a positive value of .410 and $B$ value is 0.390 .

Table 4

Coefficient

\begin{tabular}{lcccc}
\hline Model & B & Std. Error & T & Sig. \\
\hline PU & .289 & .076 & 3.805 & .000 \\
PEU & .390 & .091 & .425 & .000 \\
PV & .146 & .084 & 1.747 & .000 \\
PE & .275 & .085 & 3.240 & .000 \\
PIN & .171 & .068 & 2.506 & .000 \\
P & .213 & .066 & .200 & .000 \\
\hline
\end{tabular}

a. Dependent variable: $\mathrm{P}$

The third hypothesis shows the effect of perceived value on purchase intention found a significant relationship with a positive value .390 and $\mathrm{B}$ value is 0.146 . The fourth hypothesis shows the effect of perceived enjoyment on purchase intention and found a significant relationship with a positive value .461 and $\mathrm{B}$ value is 0.275 . The fifth hypothesis shows the effect of personal innovativeness on purchase intention and found a significant relationship with a positive value .433 and $B$ value is 0.17 . The sixth hypothesis shows the effect of price on purchase intention it find out a significant but positive relationship with a positive value .301 and $B$ value is 0.213 which means that the sixth hypothesis was rejected. Hence the result shows that there are positive relations between independent variables and dependent variable for $3 \mathrm{G}$ and five hypotheses has been accepted, while one hypothesis is rejected.

\section{Discussion and recommendations}

\subsection{Discussion}

The end result of this research shows that the effect of perceived usefulness on purchase intention of $3 \mathrm{G}$ technology and it revealed a positive significant relation as previously studied by Suki (2011), Baran (2009), Phuangthong and Malisawan (2005), Suki and Suki (2011). The second hypothesis tells the conclusion of perceived ease of use on purchase intention of $3 \mathrm{G}$ technology and result revealed a positive significant relation as previously studied (suki, 2011; Baran, 2009; Phuangthong \& Malisawan, 2005; Suki \& Suki, 2011). The third hypothesis show the effect of perceived value on purchase intention of $3 \mathrm{G}$ technology and result revealed a positive significant relation as previously studied (Agarwal et al., 2007). The fourth hypothesis shows the effect of perceived enjoyment on purchase intention of $3 \mathrm{G}$ technology and result revealed a positive significant relation as previously studied (Suki, 2011; Baran, 2009; Phuangthong \& Malisawan, 2005). The fifth hypothesis shows the effect of personal innovativeness on purchase intention of $3 \mathrm{G}$ technology and result revealed a positive significant relation as previously studied (Baran, 2009). The sixth hypothesis show the effect of price on purchase intention of $3 \mathrm{G}$ technology and result revealed a positive significant relation as previously studied (Sun, 2007; Fida et al., 2014) which was totally opposite to the hypothesized relationship.

\subsection{Conclusions and implications}

From the results it has been concluded that all the independent variables have a very significant role in shaping the intentions of consumers towards purchase of $3 \mathrm{G}$ technology. Price was negatively hypothesized with PI but results show that it positively affects PI which means Price skimming is the best strategy in case of $3 \mathrm{G}$ technology in its introduction and growth phase in transitional regions like Haripur. 3G providing companies can learn a lesson from this result and can focus their promotional efforts on these six variables as they are vital in positively molding consumer mind. 


\subsection{Limitations and future research}

Every research endeavor is subject to limitations and same is the case with this study. These limitations actually pave the way for future research opportunities. Future studies of TAM and 3G in Pakistan can focus on comparison of different age groups as this study was only focused on Millennials. Another study can also increase independent variables to bring more robustness into the model. Sample size can also be expanded to other cities and comparison can be done among them. $4 \mathrm{G}$ technology's acceptance can also be studied in Pakistan using TAM.

\section{References}

Adclout, (2013). Smartphone trend increasing here in Pakistan. http://adclout.com/blog/smart-phonetrend-increasing-here-in-pakistan

Adams, D. A., Nelson, R. R., \& Todd, P. A. (1992). Perceived usefulness, ease of use, and usage of information technology: a replication. MIS quarterly, 16(2), 227-247.

Agarwal, R., Sambamurthy, V., \& Stair, R. M. (2000). Research report: the evolving relationship between general and specific computer self-efficacy an empirical assessment. Information Systems Research, 11(4), 418-430.

Ali, S. M. (2013). Challenges and security issues in future IT infrastructure components. International Journal of Computers \& Technology, 8(2), 845-847.

Ali, S. M., Jilani, T. A., Kidwai, A., Noor, H., \& Shah, R. (2015). University Students' Perception on the Impact of $3 \mathrm{G}$ Mobile Broadband in Pakistan-A Survey.

Bakar, M. S. A., \& Bidin, R. (2014). Engaging Users Using Movie Mobile Advertising: Technology Acceptance and Purchase Intention. Asian Social Science, 10(7), 129.

Davis, F. D. (1989). Perceived usefulness, perceived ease of use, and user acceptance of information technology. MIS quarterly, 13(3), 319-340.

Davis, F. D., \& Venkatesh, V. (1996). A critical assessment of potential measurement biases in the technology acceptance model: three experiments. International Journal of Human-Computer Studies, 45(1), 19-45.

Davis, F. D., Bagozzi, R. P., \& Warshaw, P. R. (1992). Extrinsic and intrinsic motivation to use computers in the workplace1. Journal of Applied Social Psychology, 22(14), 1111-1132.

Enck, W., Octeau, D., McDaniel, P., \& Chaudhuri, S. (2011, August). A Study of Android Application Security. In USENIX security symposium (Vol. 2, p. 2).

Fida, S., Ahmed, M. A., Nazar, R., Khan, Z., \& Zahid, Z. (2014). The Elements of Consumer Attitude toward Service Innovation- An analysis of $3 \mathrm{G}$ and $4 \mathrm{G}$ technology in Pakistan. International Journal of Management Sciences and Business Research, 3(8), 29.

Grant, I., \& O'Donohoe, S. (2007). Why young consumers are not open to mobile marketing communication. International Journal of Advertising, 26(2), 223-246.

Gefen, D., Straub, D., \& Boudreau, M. C. (2000). Structural equation modeling and regression: Guidelines for research practice. Communications of the association for information systems, 4(1), 7.

Garg, A. K., \& Garg, D. (2013). An assessment of 3G Internet service acceptance in Botswana: Technology acceptance model with social influence and price perception. Pakistan Journal of Social Sciences, 33(1), 47-60.

Hsu, C. L., \& Lu, H. P. (2004). Why do people play on-line games? An extended TAM with social influences and flow experience. Information \& Management, 41(7), 853-868.

Kates R., Leiserowitz A., \& Parirs A. (2006). Great transition value, present attitude and future changes. GTI paper series frontier of great transition (9).

Kuo, Y. F., \& Yen, S. N. (2009). Towards an understanding of the behavioral intention to use 3G mobile value-added services. Computers in Human Behavior, 25(1), 103-110. 
Kumar, S. (2013). The moderating factors of 3G user acceptance technology in Shimla (India) using UTAUT model. International Journal of Computer Science \& Engineering Technology, 4(6), 670674.

Karjaluoto, H. (2007). An investigation of third generation (3G) mobile technologies and services. Contemporary Management Research, 2(2), 91.

Legris, P., Ingham, J., \& Collerette, P. (2003). Why do people use information technology? A critical review of the technology acceptance model. Information \& Management, 40(3), 191-204.

Lederer, A. L., Maupin, D. J., Sena, M. P., \& Zhuang, Y. (2000). The technology acceptance model and the World Wide Web. Decision support systems, 29(3), 269-282.

Lin, C. Y., Fang, K., \& Tu, C. C. (2010). Predicting consumer repurchase intentions to shop online. Journal of Computers, 5(10), 1527-1533.

Lin, T. C., Wu, S., Wang, K. I., \& Tsai, M. C. (2015). Factors affecting third-generation mobile services: Applying the purchase intention model. Journal of Organizational Computing and Electronic Commerce, 25(1), 47-75.

Maoyan, Zhujunxuan, \& Sangyang (2014). Consumer purchase intention research based on social media marketing. International Journal of Business and Social Science, 5(10), 92-97.

Mardikyan, S., Beşiroğlu, B., \& Uzmaya, G. (2012). Behavioral intention towards the use of 3G technology. Communications of the IBIMA, 10.

Ngai, E. W., Poon, J. K. L., \& Chan, Y. H. C. (2007). Empirical examination of the adoption of WebCT using TAM. Computers \& Education, 48(2), 250-267.

Pagani, M. (2004). Determinants of adoption of third generation mobile multimedia services. Journal of Interactive Marketing, 18(3), 46-59.

Persaud, A., \& Azhar, I. (2012). Innovative mobile marketing via smartphones: are consumers ready?. Marketing Intelligence \& Planning, 30(4), 418-443.

Phuangthong, D., \& Malisawan, S. (2005, August). A study of behavioral intention for 3G mobile Internet technology: Preliminary research on mobile learning. In Proceedings of the Second International Conference on eLearning for Knowledge-Based Society (pp. 4-7).

Rogers, E. M. (1995). Diffusion of innovations (4th ed.). New York: Free Press. Schultz, B. (2001). The m-commerce fallacy. Network World, 18(9), 77-82.

Singh, S., Singh, D. K., Singh, M. K. \& Singh, S. K. (2010). The forecasting of 3G market in India based on revised technology acceptance model. International Journal of Next-Generation Networks, 2(2), 61-68.

Solomon, M. (2009). Consumer behavior buying, having, and being (8th ed.). Upper Saddle River, NJ: Pearson Prentice Hall.

Sultan, F., \& Rohm, A. (2005). The coming era of" brand in the hand" marketing. MIT Sloan Management Review, 47(1), 83.

Sung, J., \& Yun, Y. (2010). Toward a more robust usability concept with perceived enjoyment in the context of mobile multimedia service. International Journal of Human Computer Interaction, 1(2), $12-32$.

Shroff, R. H., Deneen, C. D., \& Ng, E. M. (2011). Analysis of the technology acceptance model in examining students' behavioural intention to use an e-portfolio system. Australasian Journal of Educational Technology, 27(4), 600-618.

Suki, N. M. (2011). Subscribers' intention towards using 3G mobile services. Journal of Economics and Behavioral Studies, 2(2), 67-75.

Suki, N. M., \& Suki, N. M. (2011). Exploring the relationship between perceived usefulness, perceived ease of use, perceived enjoyment, attitude and subscribers' intention towards using $3 \mathrm{G}$ mobile services. Journal of Information Technology Management, 22(1), 1-7.

Suki, N. M., (2011). Factors affecting Third Generation (3G) mobile service acceptance: evidence from Malaysia. Journal of Internet Banking and Commerce, 16(1), 1-12.

Ting, D. H., Lim, S. F., Patanmacia, T. S., Low, C. G., \& Ker, G. C. (2011). Dependency on smartphone and the impact on purchase behaviour. Young Consumers: Insight and Ideas for Responsible Marketers, 12(3), 193-203. 
Taylor, S., \& Todd, P. A. (1995). Understanding information technology usage: A test of competing models. Information systems research, 6(2), 144-176.

Zeithaml, V. A. (1988). Consumer perceptions of price, quality, and value: a means-end model and synthesis of evidence. The Journal of Marketing, 52(3), 2-22.

Zarrad, H., \& Debabi, M. (2012). Online purchasing intention: Factors and effects. International Business and Management, 4(1), 37-47.

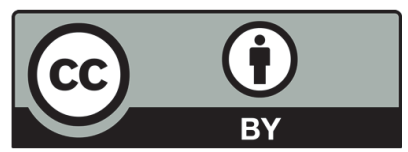

(C) 2016 by the authors; licensee Growing Science, Canada. This is an open access article distributed under the terms and conditions of the Creative Commons Attribution (CC-BY) license (http://creativecommons.org/licenses/by/4.0/). 